\title{
Use of outsourcing in practice of slovak companies
}

\section{Lucia Badáňová, Elena Thomasová}

University of Economics in Bratislava, Faculty of business management, Department of management, Dolnozemská cesta 1/b, Slovakia

\section{Email address:}

badanoval@gmail.com, (L. Badáňová), thomasov@euba.sk (E. Thomasová)

\section{To cite this article:}

Lucia Badáňová, Elena Thomasová. Use of Outsourcing in Practice of Slovak Companies. International Journal of Economics, Finance and Management Sciences. Vol. 1, No. 1, 2013, pp. 43-53. doi: 10.11648/j.ijefm.20130101.16

\begin{abstract}
The article shows the view of outsourcing in Slovak conditions in years 2009-2010. Authors would like to present their results of the research made in Slovak companies follow the domestic and foreign point of view to outsourcing.
\end{abstract}

Keywords: Outsourcing, Supplier, Core Business, Resources

\section{Introduction}

The term of outsourcing comes from English words "Outside Resource Using", what absolutely describes the nature of outsourcing - the realization of business processes by external resources. Outsourcing is the process, when chosen business activity is transferred to external supplier of this activity. External supplier provides this activity or process and also responses for this activity. [12]. Outsourcing is used in long-term as a tool of streamlining management processes. This strategic tool is starting to be used also in public sector. We can say that in Slovak conditions, there is still distrust of management tools such as outsourcing. It's not because they missed encounter without sourcing projects, but because the Slovak managers have a mistrust of the external organization, which should provide some activities of their business. According Slávik [19], for small and medium companies it is hard to spend money for external organization, even if they realize the need of specific skills, which external provider has.

It is necessary to overcome this scepticism, since outsourcing becomes a tool that delivers a competitive advantage. Companies that have taken lessons from abroad or from successful outsourcing projects, overcome this distrust. The main barrier is that outsourcing does not become common part of corporate strategic plans; rather it is considered one of the ways reducing operating costs. Slovak firms have not yet learned to make detailed economic analysis of internal processes; they are unable to separate their main activity from support processes.

\section{Current Approaches to Business Process Outsourcing}

\subsection{Scope Knowledge of Outsourcing in Domestic and Foreign Literature}

Outsourcing is the replacement of its own business activities, carried out so far in the business activity, acquired outside the company. It is the exclusion of activities that are not the main business of the company (the core business), to increase efficiency. Outsourcing was created in response to the fact that for many businesses was already unbearable and even unimaginable for many reasons (financial and personnel), to ensuring that all processes required for long-term level of their own.

In the literature we meet with the term "business process outsourcing." According to Brown and Wilson [2], is the act of outsourcing procures services from external sources. Business process outsourcing occurs when a company decides to transmit management of a specific process in the organization (eg. accounting) to a third party, which is specialized in the area.

The main features of outsourcing include [6]:

- Long duration, long-term contact

- Supplier as the partner,

- A strong partner,

- Decision on outsourcing takes place at the strategic level,

- The activity is no longer done in-house.

According Halvey and Melby [9], in many ways, today we live and work in the so-called. outsourcing world more than ever before. This is the basic principle of business operations is to use the outsourcing model for all but especially for a growing number of business functions in this world will not enter into the competitive advantage of products and services offered by the company. Conversely competitive differentiation comes as a result of proper selection of a number of features that a company outsources mainly based on skill with which these functions are managed. 
The main idea of the traditional understanding of the planning and management process is to get them all on your own "in house". However, this operation is financially, technically and personnel-intensive.[3]

Based on a survey made by PricewaterhouseCoopers in 2009 for a sample of 226 of its clients, we can say that the mostly outsourced area is services in information technology, whether it is a complete or partial outsourcing. More services are also used in the field of logistics and human resources or supply main services. Other results of the survey shows the following chart (Figure 2).

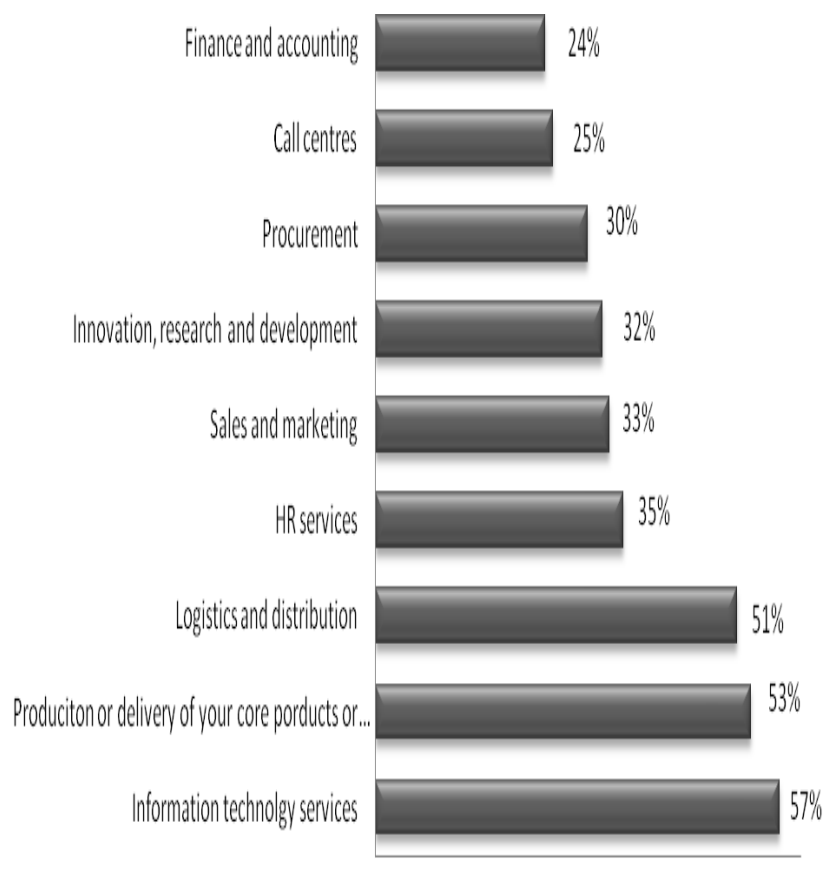

Figure 2. The use of outsourcing [16]

\subsection{Outsourcing Versus Insourcing}

The opposite of outsourcing is called insourcing, thus ensuring its own activities, resources ,in-house“. Respectively, outsourcing means also withdrawal from the outsourcing contract. Such withdrawal may have taken a number of reasons (eg, rising costs, inadequate choice of outsourcing partner, of dependence on the service provider, etc.).. Insourcing is the ideal solution for businesses that take up less space market, sell higher-margin products and their competitive advantage is not price but quality.

Companies tend to return to the insourcing in times of crisis, when there is a release of internal capacities and their businesses are trying to use these capacities the most. Another reason is beacause demand is changing and the need for a flexible response to it is necessary. This means that all operations must be close to the main field of application. For example, from the middle of the 20th century, American businesses have begun to prefer Asia, because of the growing volume of production was more advantageous for companies to produce overseas. Over time, the ocean logistics infrastructure greatly intensified too. Its flexibility has increased to such an extent that allowed companies largely operate in just-in-time fashion without the need to build another huge storage space. But several U.S. companies have so far preferred this model begin to reassess the situation. They limit or cancel production in Asia and move closer to the market,. "Long delivery chain is not a problem if the demand is stable. But the problem is, when production increases or decreases, "says vice president of American furniture company Kathy Ireland Karl Eulberg. [15]

Advantages and disadvantages of insourcing

Insourcing, like outsourcing, has several advantages but also disadvantages that by varying degrees affect the decision on its use in business. It is therefore essential that managers devote time and effort to risk analysis and effects that carry the outsourcing but also sourcing.

According to Bruckner and Voříšek [3] the main advantages of insourcing solutions include high capacity to solve operating problems because the business is conducted "at home" in the company, then it is less risk of leakage of information and know-how. One of the major advantages of insourcing by these two authors is the fact that employees often perform additional work beyond that are the result of their efforts to help and skills in the field. These benefits should be made aware of the outsourcing providers, because it is a fact, whether they are trivial or important benefits, and it affects the demand for the service they provide. On the other hand, disadvantages of insourcing is the difficultly to maintain competitiveness at world level in terms of less flexibility in secondary activities. The disadvantage is the need for investment in areas beyond the main activities of the company and also the risk of stagnation. The authors also see the disadvantage in the issue of the responsibility for the area.

The very important factor working in favor of insourcing is that insourcing reduces dependence on external suppliers. The side effect of insourcing is communication, which is characterized by informality and creating interpersonal relationships that are part of the business climate. Their effects may be both positive and negative.

According Hučka, Kislingerová and Malý [10] the outsourcing is one of trend of the future, which will significantly influence the architecture of the company. But businesses are trying to avoid outsourcing activities that:

- Are critical to the success of the final product or service to the customer

- Require special knowledge and skills, technology or a number of potential suppliers is limited,

- Related to the core responsibilities of the company

- Are important for the synergistic effects that arise in society.

Companies in the selection of suitable activities use mainly outsourcing experience and empirical methods, based mainly on determining the criteria for which activities are suitable for outsourcing.

\subsection{Reasons for Outsourcing}

Tendency today is to outsource more and more beacause outsourcing is the way how to increase competitiveness of business processes to reduce costs. But not only these reasons are the main causes for implementation of this phenomenon in corporate practice. (Figure 3 ) 


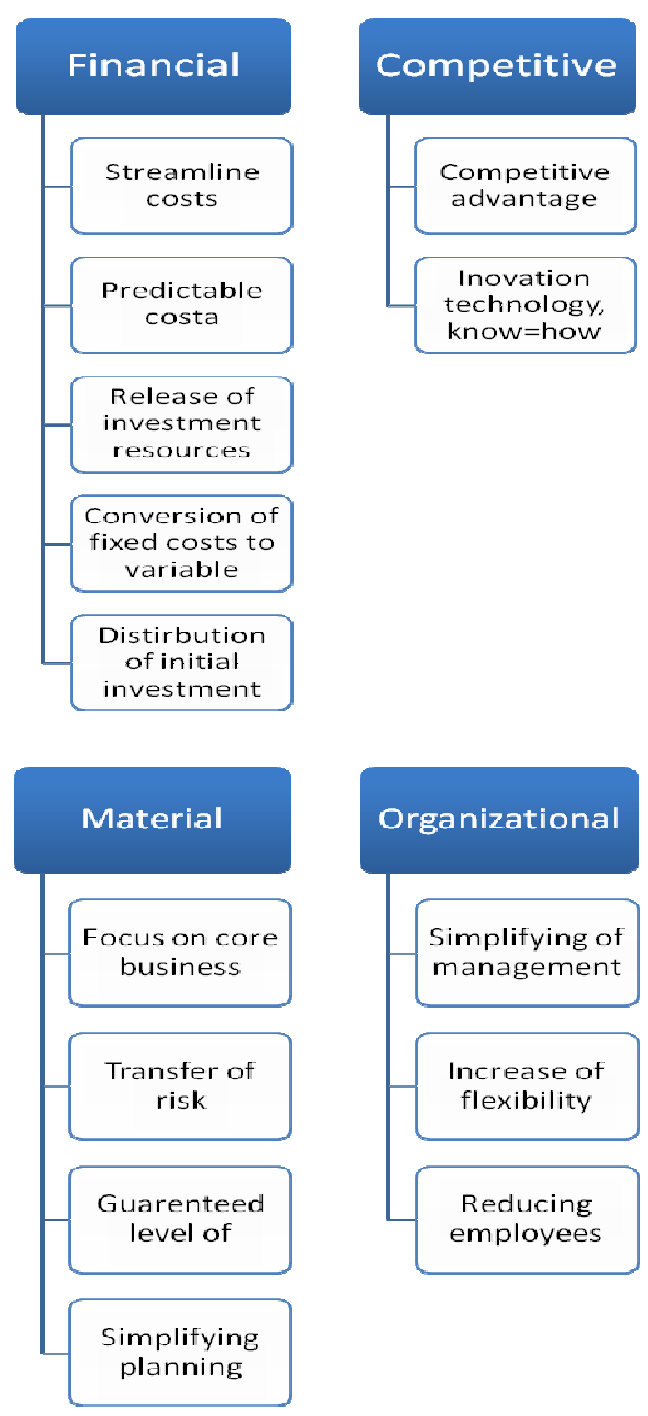

Figure 3. The most important reasons for outsourcing [3]

The main reason for exclusion of business activities is the concentration on core activities that ensure the survival of the company. Outsourcing should ensure greater responsiveness, accuracy and the overall competitiveness of the company. Ultimately, no matter whether it is the nature of the business of production or providing services. Thus, the company moved part of processes not directly related to the implementation of the product to provider; it remains greater scope and opportunities for improvement and streamlining those processes, which directly affect and impact its core business. For these processes usually has more time and money.

Finally, one of the major reasons for outsourcing is quantity and quality of experience that service providers have. They are mostly experts, whose main area of activity is just work, they handle. They have a long experience in the field; they can assess potential risks and hidden pitfalls, because they met with them in the past. All this enables their clients to not make but to successfully avoid mistakes.

Lack of licensing or authorization to perform certain specialized services is also considered one of the reasons for outsourcing (eg. storage and handling of hazardous substances).

In the field of human resources, a significant benefit of outsourcing is not only connected with the various seasonal fluctuations but also with a stable demand for employees. The client does not care about recruiting, sourcing, recruitment, simply enter your partner a requirement for all personnel and responsibilities and the process moves on him. The human resources tend to assign the payroll, administration and so on provider.

The decisive argument why to outsource is clearly the financial aspect. Well-designed business process outsourcing solutions can save considerable money by streamlining processes. The financial aspect is closely related to costs in the outsourcing relationship changed from fixed to variable. An example is the area of storage or transport. If the company owns a car park, warehouse, or the other fleet, resulting in each case are the fixed costs (eg depreciation), although their equipment and buildings not used. These costs tend to represent a negligible percentage of the total cost. However, if the company decides to outsource this area of activity, fixed costs will fall away and transferred to a provider who billed the client a price equal to the actual diversion performance. In this case, therefore it has a variable cost.

In relation to the cost aspect of outsourcing should act very carefully. The decision on allocation of a specific area of business for financial reasons should consider the market mechanism on one side and the other for internal planning. While there is no company in the market environment, external suppliers are in it. Business activities are the result of internal (administrative) planning, which believes that it is more rational than on market. However, this internal planning is inconsistent with Smith "invisible hand of market", so we seem to appear that there is a conflict. Therefore, by outsourcing to take place only if it carries on its business processes with higher costs (including all costs, and planning), than those that would be spent if it ensures the different business processes.

The decision to outsource is very difficult and the implementation of outsourcing raises many questions regarding appropriate objectivity, rationality and problem solving. These questions usually arise in the business for the following reasons [17]:

- Reduce and control operating costs

- Access to new know-how,

- Unavailability of the necessary resources - internally

- Reduction of investment costs

- Transfer of risk

- Improve the quality of business processes,

- Improve cash flow,

- Freeing capacity on "core business"

- Cash from the sale of equipment providers,

- Release of internal resources for other activities.

\subsection{Risks of Introducing Outsourcing}

The risk factors may affect the outcome of actions, activities, and therefore business. It is most often seen as the probability of loss or failure. The decision on outsourcing is often associated with a direct impact on the whole com- 
pany, its value, future direction and financial situation. It is usual phenomenon that we encounter in business practice with the problems and disadvantages associated with outsourcing. With the introduction of outsourcing failure and its management during the outsourcing relationship is related to the risk of undermining society. Managers must be aware of potential problems and negative aspects asso- ciated with the use of outsourcing, for example [20]:

$>$ costs of coordination: difficulties may occur particularly in reconciling production with external providers,

$>$ problems with quality and service: in general, there is the tendency to rely on the quality, but quality is, on the other hand, difficult to verify,

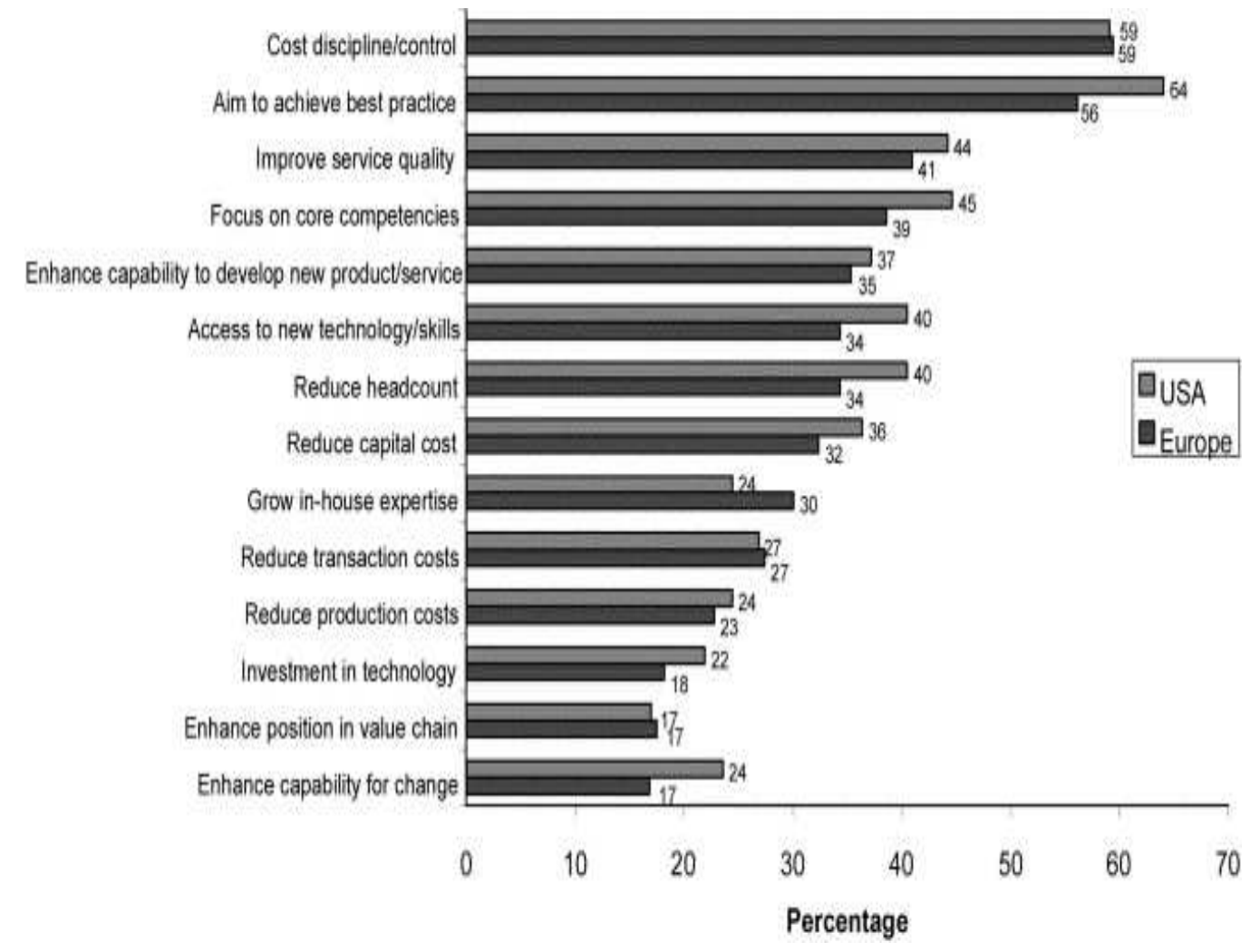

Figure 4. Reasons for outsourcing: USA vs. Europe [4]

It is interesting to look at the reasons that lead to outsourcing companies in America, compared with companies operating in Western Europe.

In the U.S., look at outsourcing from a procedural point of view - the reasons are more focused on improving the "core business" growth of knowledge, access to new technologies. In Europe, outsourcing leads to a more cost perspective. An overview of reasons behind outsourcing in the U.S. versus Europe brings the graph (Figure 4).

$>$ control: outsourcing can cause loss of control over key areas, not excluding employee relations and managing staff,

$>$ dependence on the service provider: it may be due to poor control of the outsourcing relationship and market monitoring,

$>$ risk arising from the disadvantages of the contract for the delivery of services and influence the environment in terms of cooperation with service providers and the risk of failure of cooperation,

$>$ internal ignorance of the real costs: failure to meet initial expectations of cost reduction (customer miscalculated all the original internal costs),

$>$ from the perspective of the provider, there is usually required very good knowledge of the client, if necessary its strategic goals and plans.

Since the decision on outsourcing is a long-term, it means strategic, decision-makers or employees and managers involved in this process should consider not only the difficulty of using the outsourcing but should also take into account the strategic position of the company, its resources and capacity. Although cost analyses speak in favor of outsourcing, there may also be many unforeseen circumstances that cause other direct and indirect costs that may outweigh the benefits.

These disadvantages are inherent advantages of insourcing -it is ensuring services within the company. Providers should be made aware of these benefits of the outsourcing, because it is a fact, whether they are trivial or important, it affects the demand for the service they provide.

It is important to realize that outsourcing is not an option only for large companies. Over the last thirty years, number of small and medium enterprises has grown such as their contribution to outsource various activities. Many companies provide specialized services available for small companies.

In the case of outsourcing risks can be eliminated thorough analysis of the risk outsourcing relationship. For smaller companies, where all the decision to outsource cost more or less to the owner or executive officer, risk analyzes is not performed, or they are very superficial. In some cases, the outsourcing company is the only possible solution for ensuring the activity (for example, in the absence 
of internal sources).

List of advantages and disadvantages of outsourcing

gives the following table (Table 1).[18]

Table 1. Advantages and disadvantages of outsourcing

\begin{tabular}{|c|c|c|}
\hline & ADVANTAGES & DISADVANTAGES \\
\hline \multirow{6}{*}{ STRATEGIC } & iocu on core-business & Loss of control over the outsourced area \\
\hline & Do the activity on expert level & Loss of contact with customer \\
\hline & Access to new markets & Leakage of confidential information \\
\hline & Access to international logistics networks & Loss of ability to respond to changes in customer needs \\
\hline & Higher customer satisfaction & Resistance to change by employees \\
\hline & More flexibility & \\
\hline \multirow{7}{*}{ FINANCIAL } & Economies of scale & Jonrealistic fee structure and financial loss \\
\hline & Lower capital investment & Dependence on provider \\
\hline & Lower services cost & Problems with a estimated cost saving \\
\hline & Lower financial risk & \\
\hline & Change fixed costs to variable & \\
\hline & Lower labor costs & \\
\hline & Possibility of benchmarking in logistics costs & \\
\hline \multirow{6}{*}{ OPERATING } & Better use of capacity & Weak information system \\
\hline & More flexibility in capacity use & Lower customer service \\
\hline & Lower stock & Large differences in corporate culture of provider \\
\hline & Shorter order cycle & Lack of qualification \\
\hline & Reducing production preparation & Technological failure \\
\hline & Access to logistics operating systems & \\
\hline
\end{tabular}

\section{Research of Outsourcing in the Prac- tice of Slovak Companies}

In the following part we would like to show the results of research, made in companies in Slovakia, concerning use of outsourcing.

\subsection{Characteristics of Respondents}

We would like to explain to the situation in the area of outsourcing in Slovakia, we have mapped out through a questionnaire survey. This survey was realized in Slovak republic in the years of 2009 and 2010. The sample of chosen companies represents 100 organizations. The characteristic of companies is listed according to their size and scope activities.
As shown in the following chart (Figure 5), more than $37 \%$ of surveyed companies has up to 9 employees, $30 \%$ of respondents has up to 49 employees. Together they form more than $67 \%$ of enterprises surveyed. According to the Statistical Office Slovak Republic, in Slovakia there are $98.97 \%$ of companies just up to 49 employees.

The surveyed companies are characterized by up to $50 \%$ of companies had turnover for the years 2009 and 2010 to 2 million Euro.

In 2009 more than $78 \%$ asked companies earned profit, similar in the year 2010 , where $83 \%$ of respondents made a profit. Percentage of profitable businesses for the past four years gives the following graph (Figure 6).

Surveyed companies were from the area of trade $22 \%$, production $33 \%$ and services $45 \%$. In terms of core business, most enterprises are in industry, construction and wholesale and retail trade. The surveyed companies are 
also represented in the agriculture, forestry, financial services and some types of logistics services such as storage and transport, but also in formation technology and hospitality services. The questionnaire also reflects business government, educational institutions. In the survey, all respondents were represented according to the classification of economic activities SK NACE. An overview of the structure business according their focus comes in Table 2.

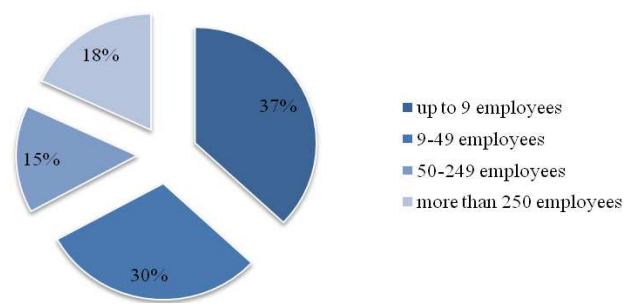

Figure 5. Surveyed companies according the number of employees [1]

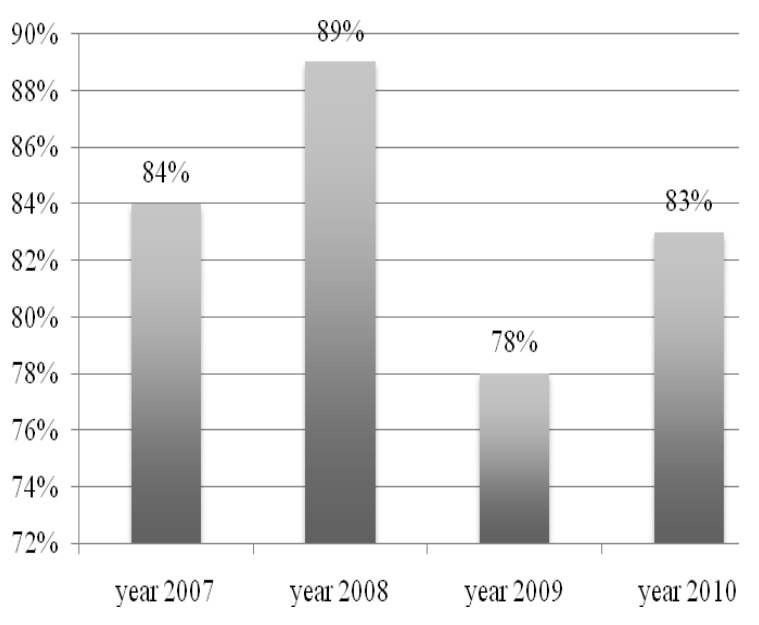

Figure 6. Percentage of profitable companies [1].

Table 2. Surveyed companies according their focus [1]

\begin{tabular}{|c|c|}
\hline Main focus of activities & Share of responedents \\
\hline Agriculture, Forestry and fishing & $8 \%$ \\
\hline Manufacturing & $17 \%$ \\
\hline Electricity, gas & $2 \%$ \\
\hline Water supply & $1 \%$ \\
\hline Construction & $18 \%$ \\
\hline Wholesale and retail & $19 \%$ \\
\hline Transport and storage & $5 \%$ \\
\hline Accommodation and foodservices & $3 \%$ \\
\hline Information and communication & $2 \%$ \\
\hline Financial and insurance activities & $5 \%$ \\
\hline Real estate activities & $3 \%$ \\
\hline Professional, scientific and technical activities & $8 \%$ \\
\hline Administrative and support services & $2 \%$ \\
\hline Public administration and defense & $2 \%$ \\
\hline Education & $3 \%$ \\
\hline Arts, entertainment and recreation & $2 \%$ \\
\hline
\end{tabular}

In terms of scope, the majority of respondents replied that it operates regionally (31\%) and nationally (30\%). At the local level works $11 \%$ of respondents. The survey showed that $19 \%$ of respondents operate on a transnational level and $9 \%$ of companies said they will move to world markets. Overall, that the Slovak market operates more than half of respondents and only less than a third of businesses are moving to markets beyond Slovakia.

\subsection{Use of Outsourcing by Respondents}

In the second part of the questionnaire, participants were asked to field of outsourcing.

Deciding on outsourcing is mainly on the top management - up to $85 \%$ of businesses stated that whether or not to use outsourcing decision is on top management. $12 \%$ of respondents said that outsourcing decided by mid-level manager, and $3 \%$ of companies involved in decisions on outsourcing regular employee.

When asked whether they use outsourcing, almost half said they do. More than a third of companies outsourcing does not use. More data are in the following graph (Figure 7).
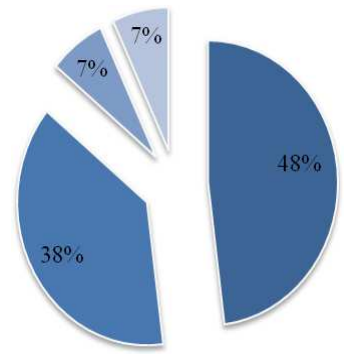

mes
mo
m considering of outsourcing
m does not know this notion

Figure 7. Use of outsourcing [1]

The search shows that outsourcing is dominated in large companies, which have over 250 employees. In contrast, outsourcing is used only third of respondents among the companies that have up to 9 employees.

Costs of outsourcing in the surveyed companies represent on average $20 \%$ of total company costs.

If respondent does not use outsourcing, we asked why. The reasons are several, the most common, that their own 
employees which are able to provide all the activities well enough. Up to one fifth of respondents who said they do not use outsourcing, it's because they do not trustexternal service provider and have fear of misuse of information. $5.5 \%$ respondents consider outsourcing in a risky and it is expensive for $3.5 \%$.

The survey also showed that companies that use outsourcing are in most of the beneficiaries for a long time. A majority of respondents use outsourcing for more than three years. Quarter of respondents outsource less than 3 years but more than 1 year. It is mainly about outsourcing in Slovakia. An overview on the use of outsourcing in terms of geography is shown in the table (Table 3 ).

The survey confirmed that outsourcing within whole world is used only by multinational manufacturing companies, employing over 250 employees. Mainly medium and large companies from 50 employees engaged in manufac- turing but also construction use outsourcing within European Union.

Table 3. Outsourcing in terms of geography [1]

\begin{tabular}{ll}
\hline Outsourcing within: & Share of respondents \\
\hline Slovakia & $67 \%$ \\
European Union & $24 \%$ \\
World & $9 \%$ \\
\hline
\end{tabular}

It is known that firms tend to outsource not just one but several business areas (Figure 8). From this point of view, our research shows that outsourcing is used the most in the Information Technology field but also in the Human resources field.

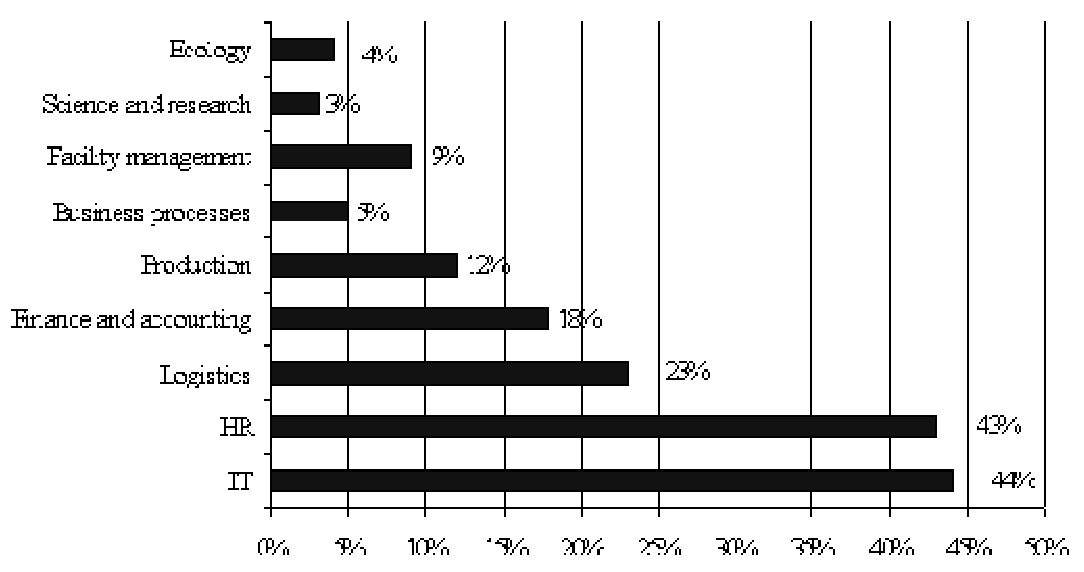

Figure 8. The areas of outsourcing used in Slovakia [1]

Interestingly, respondents from manufacturing companies (almost $50 \%$ of them) use directly outsourcing of production, either part or all production activities. The area of finance and accounting is outsourced mainly by wholesale and construction businesses or retail. Outsourcing of facility management is again the most used for companies engaged in financial services.

If you look closely at each area of outsourcing, often is not about outsourcing the whole area but only parts of it. The following Table 4 provides an overview of individual parts of three favourite outsourcing areas.

Table 4. Overview of individual parts of processes, which are outsourced in companies [1]

\begin{tabular}{ll}
\hline The areas of outsourcing & Share of respondents which outsource the area \\
\hline Information Technology & \\
Outsourcing of human resources in IT & $18 \%$ \\
Outsourcing the operation of applications & $20 \%$ \\
Outsourcing of maintenance services, development & $48 \%$ \\
Outsourcing of logistics services & $14 \%$ \\
Human resources & $35 \%$ \\
Payroll & $17 \%$ \\
Personnel search and selection & $2 \%$ \\
Employee benefits & $6 \%$ \\
Staff leasing & $33 \%$ \\
Training and education programs & $2 \%$ \\
Assessment center & $2 \%$ \\
Personal coaching & $2 \%$ \\
Outplacement & \\
Logistics & $13 \%$ \\
Outsourcing of procurement & $9 \%$ \\
Outsourcing of storage & $78 \%$ \\
Outsourcing of transport & \\
\hline
\end{tabular}

Despite these results, the longest outsourcing relationship is in accounting, production and wages. The area ofIT is still "young" area that is the subject of outsourcing relationships. 
Cosourcing integrates both in-house and outsourcing model. $20 \%$ of respondents use also cosourcing in their companies. The half of them answered, the area of cosourcing is audit, $30 \%$ indicated that they cosource some production activities in the company and $15 \%$ cosource some human resources area (education).

Multisourcing is a new functional model, which includes services from various sources toachieve the best possible result. Multisourcing delivers all the benefits of outsourcing, but also allows businesses to focus capital and resources, on which matter most to firms. It is part of corporate strategy. [2] The question about multisourcing was answered by very small percentage of respondents. Nevertheless, this notion was adequately explained and, in our opinion, the multisourcing is extensively used in companies. In $5 \%$ of respondents who answered the question we have always met with positive response and the preferred area for these companies is transport.

Companies that use outsourcing expected from outsourcing cost reductions and especially specialization, it means focus on core business. More than a third of respondents expected an increase in performance business and business processes, $31 \%$ expected increase of flexibility and $28 \%$ before the implementation of outsourcing expected that they will release internal outsourcing employees on other activities. Conversely, one third of companies surveyed joined the outsourcing due to lack of internal capacity as we can see in following graph (Figure 9). Only 11\% of respondents led to decision of outsourcing approach to innovation. $4 \%$ of respondents expected cash inflows and only $2 \%$ adopted outsourcing as an unalterable decision of top management.

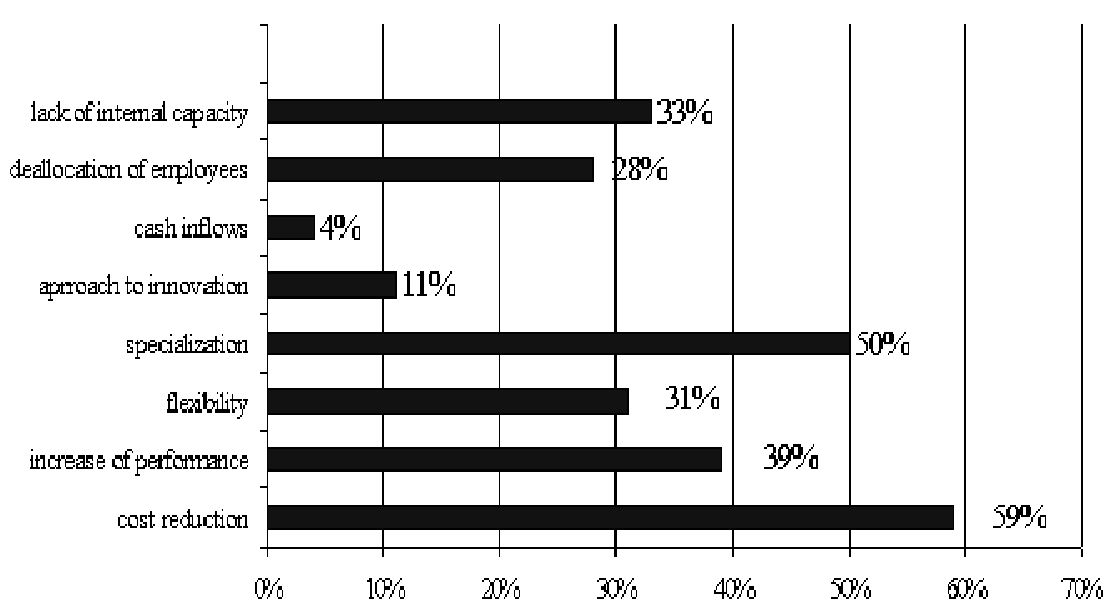

Figure 9. Expectations from outsourcing [1]

Based on the survey results we noted that expectations of cost reduction were filled to $78 \%$. It means that not all companies reduced costs and achieved their expectation. Similarly, the specialization and efficiency outsourcing brought only to $81 \%$ of companies, which had these expectations. 94\% of respondents filled expectations of increasing flexibility. Release of capacity through outsourcing has reached $60 \%$. On the contrary approach to innovation, as the expectation of outsourcing was fulfilled by $83 \%$.

On the other hand, the respondents met with risks after implementation the business outsourcing. The main and the biggest cause of dissatisfaction of outsourcing has been contacted by the fact that they have become dependent the outsourcing provider. It is greater for companies providing services that belong to small and medium enterprises with a turnover of up to 2 million Euros. They outsource in Slovakia and what is interesting have the long-term outsourcing experience and use outsourcing in several areas. On this issue further follow-up risks as leakage of confidential information, loss of contact with customers and team fall and lower customer service.

The survey also shows that companies are faced with other failures of outsourcing as a technological failure of the outsourcing provider, loss of control the outsourced area, resistance to change by employees and leak of confidential information. The other risks were also large differ- ences incorporate culture between the provider and recipient of outsourcing, loss of contact with customers, inadequate qualification of the service provider.

In the field of outsourcing, it is very important whole process, starting with planning. $68 \%$ of respondents replied that it had not prepared plan before they

implement the outsourcing and nearly all of these companies faced a problem depending on the provider of outsourcing, an even more problems. Only a third of those surveyed had a plan to roll outsourcing as part of its planning system and these companies faced fewer problems with outsourcing.

Next, we asked the respondents if there is a person responsible for managing outsourcing relationship. A quarter of respondents said that there is no one oversees this area as well as formally, and these companies had not developed an implementation plan for outsourcing. In 39\% of the respondents is a person who supervises outsourcing relationship but only formally. Only $35 \%$ of respondents employ person who formally oversees the outsourced area and regularly meets with suppliers. These companies have developed an implementation plan for outsourcing.

$16 \%$ of respondents did not inform its employees about implementation of outsourcing. $26 \%$ of respondents informed employees about the implementation of outsourcing and $56 \%$ of respondents also explained the reasons and 
procedure of implementation. It resulted that $96 \%$ of enterprises employees take the outsourcing without complications, even in companies where implementation of an employee was not notified in advance.

We investigated among the surveyed companies what organizational changes occurred after introduction of outsourcing. According Thomasová [7] it can be integration, centralization and allocation. Just over half of respondents indicated that changes did notoccur in the organizational structure. These respondents also avoided complications by employees after implementation of outsourcing, and these companies are also characterized in that use outsourcing more than 3 years. In 17\% of respondents were employees transferred to other departments (integration) and their original offices were abolished, which occurred mainly at manufacturing companies, which announced its intention to employees and the introduction of outsourcing went with out resistance from employees. $11 \%$ of respondents after the implementation of outsourcing hire new employees, these changes employees are well taken and the implementation of outsourcing, they have been notifiedand explained. $9 \%$ of surveyed companies release few employees and their departments have been abolished (allocation), which was part of a plan drawn up and all these companies implemented outsourcing because of saving costs.

\section{Conclusions from the Analysis of the Data and the Impact of the Economic Crisis on Outsourcing Partnerships}

We arrived to some conclusions after the evaluation the results of the survey according the theory of outsourcing.

Outsourcing, as the replacing internal activity by external activity, is in Slovak conditions often using. From asked respondents almost half of them use some of business process outsourcing. Mostly, it is long lasting outsourcing relationship, lasting more then three years. This means outsourcing is understood as long term strategic tool both, in the theory and also in the managerial practice, where top management makes decision about it.

The main reason of non-using of outsourcing is satisfaction with internal performance of activities but also distrust for external provider. These reasons are also reasons for insourcing. In theory we meet also with other reasons for insourcing companies do not consider such as ability to solve operating problems etc.

In Slovak conditions, the most used outsourcing area is information technology field and human resources field, such as other authors mention too. From geographical point of view, companies in Slovakia use all advantages from onshoring and nearshoring the most.

The most often mentioned reason for outsourcing is reduction of costs, but also specialization and increase of efficiency. These trends confirm also found trends in other European countries. Our companies consider less the organizational and competition advantages introduced in outsourcing theory.

Results of research show that companies in Slovakia meet with risk of outsourcing. As other authors mention, these reasons are from strategic, operational and financial field. The most common is disadvantage of dependence on provider made after some time.

In the process of outsourcing there is lack of outsourcing planning, even if this phase is considering as one of the main phases of outsourcing. On the contrary, during the discussion with employees, management explains the reasons and progress of the outsourcing implementation. As the theory says, this step is very important and it fluencies the outsourcing implementation without complications.

Companies operating in Slovakia are in turbulent conditions too, such as other companies operating in other countries. In Slovak practice, outsourcing is still the way to decrease costs instead of opportunity how to increase competition advantages. In our opinion this point of view should change in the future.

Companies in Slovakia feel the impact of economic crisis, particularly in a reduction of sales and some of them joined the layoffs, though the relationship did not change to outsourcing, as shown in the graph (Figure 10).

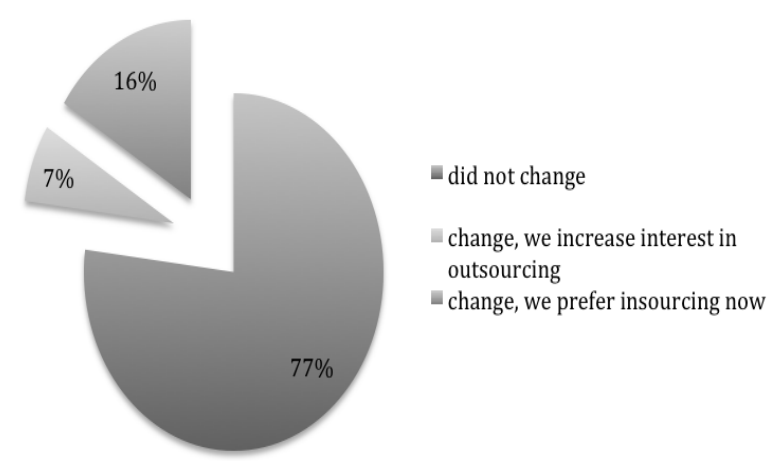

Figure 10. Changes in relationship to outsourcing during crisis [1]

Many companies today use the possibility of outsourcing processes that are important to them and focus on core business processes. In terms of Slovak companies, however, still not looking at outsourcing as opportunity, as is often referred to in the literature. From our perspective, we are on the side of authors who refer to outsourcing as a means of overcoming the crisis.

\section{The Methodology of Suitability Process Outsourcing}

According studying of literature and our research the main issue in companies in Slovakia is how to find and determine the process, which is suitable for outsourcing. In practice, the process is chosen the most often just by decision of manager without any analyses.

We suggest simple methodology applicable in practice. In this procedure, and after answering all or most of the issues should manager determine whether the process is suitable for outsourcing or not. We are aware that the evaluation of responses may vary from company to company, so there is a need for some degree of ability to objectively determine the manager's process suitable for outsourcing. In general terms we determine how to evaluate and guide to follow in case of proposed methodology. [4] 
First Step Process Description - The first prerequisite for a decision on outsourcing is able to precisely define and describe the processes taking place in business. If the manager cannot answer all questions clearly in the first step, we can say that cannot specify, evaluate or review process. This step is essential to determine whether the process is the main or side. After the description of the process the other steps of defining a suitable process for outsourcing or insourcing follow. The description of the process itself usually has no decision about outsourcing. It is starting point for further analysis.

Second step financial statement process - this step is very important to include all relevant costs of the process in order to compare the costs with the costs of insourcing.

Third Safe process working time - if process can carry out the company, enterprise has not purchased specialized technology and equipment to perform process that are in continuous operation and does not have a specific process know-how is possible to proceed with outsourcing. If there are restrictions on the process they can be divided into two groups. Either there are limitations to support the decision of outsourcing (e.g. requiring additional investment from other sources, occur frequently and temporal variation below...) Or vice versa, there may be limitations on that support insourcing (e.g. process time is closely related to the follow-up processes, etc...)

4th step process documentation - In this step manager defines if the process map is developed, respectively it can be developed. If the company planned every step of the process, defined responsibilities, activities and links be- tween activities and the process time required for its implementation, this means that in most cases, the business process is considered as the main or top and this is not recommended to outsource. However, if process sensitive information flow to and from the process, it should be carefully considered if the company may this information provide to a third party.

Fifth step productivity of the processes - In this step it is necessary to define exactly what is required productivity of the process, respectively unproductive activities do not exceed the productive. In principle, if the process is productive, it is recommended that insourcing and vice versa, if there is no such productivity, the process is suitable for outsourcing. Also, the time required for non-productive activity would not exceed the time required for productive activities.

Sixth step process control - The business practice is often the case that controls the area is neglected, even though it is a tool to improve the efficiency and quality improvement processes. If the process is not well controlled and there is no control by a third party, is most appropriate to consider such control or consider the possibility to outsource the process.

It is important to note not only one response in favor of outsourcing is for the outsourcing decision. It should be a number of responses in favor of outsourcing. The visual approach of defining a suitable process for outsourcing is shown in the figure (Figure 11).

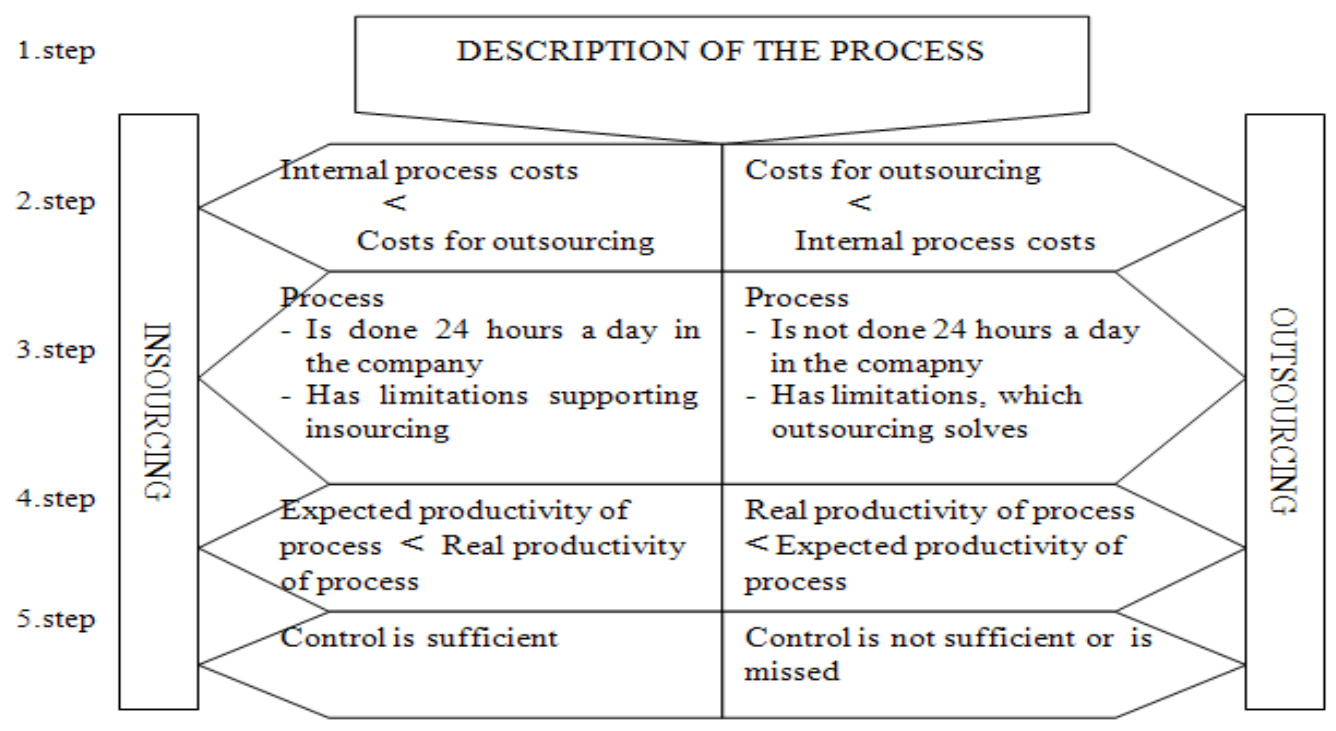

Figure 11. How to define a suitable process for outsourcing

\section{Conclusion}

According Hučka, Kislingerová and Malý, outsourcing is one of the future trends, which will be significantly influence the development of organization architecture. [3]

A search of literature, international studies and our own research show that outsourcing is a tool in the globalized world that can enhance the competitiveness of enterprises.
A survey of managers in the Slovak Republic shows that Slovak companies are aware of the possibility that this form of exclusion activity or offers in the near future.

This article was processed within project VEGA 1/0466/11 (Crisis business management).

\section{References}

[1] BADÁŇOVÁ, L. 2012. Využívanie outsourcingu podni- 
kových procesov praxi. Doktorandská dizertačná práca. 2012. Školitel': doc. Ing. Elena Thomasová, PhD. Katedra manažmentu, Fakulta podnikového manažmentu Ekonomickej univerzity v Bratislave. 120 s., 2012.

[2] BROWN D. - WILSON S. 2005. The Black Book Of Outsourcing, How to manage the changes, challenges and opportunities. New Jersey : John Wiley and Sons, Inc. 2005. 20s. ISBN 13 978-0-471-71889-5.

[3] BRUCKNER, T. - VOŘÍŠEK, J. 1998. Outsourcing a jeho aplikace při řízení informačního systému podniku. Praha : Ekopress, 1998. s. 119. ISBN 80-86119-07-6.

[4] CANIGLIA, J. - RAMACHANDRAN, K. - KHANNA, V. 2006. Business process outsourcing. (Online).(cit. 28.2.2012) dostupné na: http://www.freepatentsonline.com/y2006/0004596.html

[5] COHEN, L. - YOUNG, A. 2006. Multisourcing:moving beyond outsourcing to achieve growth and agility. USA: Gartner, 2006. 4s. ISBN 1-59139-797-9.

[6] ČERNÁ, L., - MATEJKO, P. - FRANEK, P. 2010. Poskytovanie logistických služieb $\mathrm{v}$ podniku - outsourcing. In Železničná doprava a logistika, Žilina, číslo 1, rok 2010, ročník VI. ISSN 1336-7943, s.51.

[7] DIY in Germany.Economist, 3/2/96, Vol. 338 Issue 7955, p60-60.

[8] DVOŘÁČEK, J. - TYLL, L. 2010. Outsourcing a offshoring podnikatelských činností. Praha : C.H.Beck.. 2010. 27s. ISBN 978-80-7400-010-2.

[9] HALVEY, J.K. - MELBY, B.M. 2007. Business process outsourcing: process, strategies and contracts. New Jersey : John Wiley and sons, 2007. 583s. ISBN 978-0-470-04483-4

[10] HUČKA, M. - KISLINGEROVÁ, E. - MALÝ, M. a kol. 2011. Vývojové tendence vel'kých podniků. Podniky v 21. století. Praha: C.H.Beck, 2011. 275s. ISBN 978-80-7400198-7.

[11] KAKABADSE, A. - KAKABADSE, N. 2002. Trends in Outsourcing: Contrasting USA and Europe, In European Management Journal. ISSN: 0263-2373, 2002, Vol. 20, No. 2, pp. 189-198.

[12] MAJTÁN, M. a ko. 2009. Manažment. Bratislava: SPRINT, 2009. 84s. ISBN 978-89393-07-7.

[13] MILECOVÁ, M. 2009. Ako udržat' riziko z outsourcingu pod kontrolou, In eZisk. 2009, č. 6, ISSN 1337-9151,s.3638.MORAVČÍK, T. 2009. Pevné miesto outsourcingu v logistike. In Logistika : měsíčníkvydavatelství Ekonomia. Praha : Economia, 2009. ISSN 1211-0957, únor 2009, roč. 15 , č.2, s. $26-28$.

[14] MILECOVÁ, M. 2009. Outsourcing:Rozhodovanie o vyčlenení podnikovej aktivity a riadenie outsourcingového projektu. Doktorandská dizertačná práca. 2009. Školitel': prof. Ing. Miroslav Grznár, DrSc., Katedra manažmentu. Fakulta podnikového manažmentu Ekonomickej univerzity v Bratislave. 150 s., 2009.

[15] MÚČKA, F. 2009. Outsourcing vychádza z módy. In eTrend. 2009. (cit. 25.6.2010)

http://podnikanie.etrend.sk/podnikanieriadenie/outsourcing-vychadza-z-mody.html

[16] PRICEWATERHOUSECOOPERS.2010. Outsourcing comes of age: The rise of collaborating partnering. (online). (cit.15.1.2011)Dostupné http://www.pwc.com/gx/en/consultingservices/pdfs/outsour cingcomesofage.pdf

[17] RYDVALOVÁ, P. - RYDVAL, J. 2007. Outsourcing ve firmě. Brno : Computer Press,a.s. 2007. 119s. ISBN 97880-251-1807-8.

[18] SELVIARIDIS, K. - SPRING,M. - PROFILLIDIS,V. BOTZORIS,G. 2008. Benefits, Risks, Selection, Criteria and Success Factors for Third-Party Logistics Services, In Maritime Economics\&Logistics. Rotterdam. doi:10.1057/mel.2008.12, Dec 2008. Vol. 10, Iss. 4; p. 380.

[19] SLÁVIK, Š. 200. Strategický manažment. Bratislava: SPRINT, 2005. 228s. ISBN 978-80-89393-08-4.

[20] STRENITZEROVÁ, M. 2007. Outsourcing v riadení l’udských zdrojov - áno či nie?. In Elektronický časopis Katedry spojov Pošta, Telekomunikácie a Elektronický obchod. ISSN 1336 8281, Ročník II/2007, s.48-55.

[21] THOMASOVÁ, E. 2010. Organizovanie. Bratislava: Ekonóm. 2010. 186s. ISBN 978-80-225-2914-3. Top 10 Reasons Companies Outsource. (cit. 20.1.2012), dostupné na:

http://www.outsourcing.com/content.asp?page $=01 \mathrm{~b} /$ articles/ intelligence/oi top ten_survey.html

[22] Riadenie outsourcingového rizika. (cit. 22.3.2012) dostupné na: http://outsourcing.infoweby.sk/zdielanie-rizik/riadenieoutsourcingoveho-rizika. 